\title{
INFLUENCE DE FORTES VARIATIONS DE NIVEAU EN ÉTIAGE SUR LES MOUVEMENTS ET LA DISTRIBUTION DE SAUMONS ATLANTIQUES JUVÉNILES (SALMO SALAR L;) EN FONCTION DE L'HABITAT DANS UN RUISSEAU EXPÉRIMENTAL.
}

\author{
P. DEBOWSKI (1) et E. BEALL (2)
}

(1) Inland Fisheries Institute, River Fisheries Laboratory, Reduta Zbik 5, 80-761 Gdansk, Pologne.

(2) Institut National de la Recherche Agronomique (INRA), Station d'Hydrobiologie, BP 3 , 64310 Saint-Pée-sur-Nivelle, France.

\section{RÉSUMÉ}

La réponse de juvéniles de saumon aux fortes baisses de niveau caractéristiques de l'étiage n'est pas bien connue. Trois expériences ont été menées en fin d'été dans un ruisseau artificiel comportant des séries de 3 biefs $(10 \mathrm{~m} \times 3 \mathrm{~m})$ constitués d'amont en aval de séquences d'habitat radier, plat, profond. En eau profonde, les tacons ne réagissent pas aux baisses de niveau et de débit. Dans les eaux peu profondes, ils réduisent leur activité, en particulier alimentaire, et dans des conditions critiques, une partie de la population se déplace vers la plus proche zone profonde. Les autres s'enfouissent dans le substrat. Après la montée du débit, une partie des dévalants retourne dans l'habitat radier.

\section{INFLUENCE OF DEWATERING ON MOVEMENTS AND DISTRIBUTION OF SALMON PARR (SALMO SALAR L.) IN RELATION TO HABITAT CHARACTERISTICS IN AN EXPERIMENTAL STREAM.}

\section{ABSTRACT}

The response of Atlantic salmon parr to major decreases in water levels, typical of summer low flows, is not well documented. Three experiments were conducted in an artificial stream designed with sequences of riffle, flat, and pool habitat, each habitat in a section $10 \mathrm{~m}$ long by $3 \mathrm{~m}$ wide. In deeper water, parr did not respond to water level or flow decrease. In shallow water, they reduced activity, particularly feeding, and in critical conditions a portion of the population moved into deeper water. The remainder of the parr buried themselves into the gravel. After flow increase, some of the downstream moving parr returned to the riffle habitat.

\section{INTRODUCTION}

In Spring, after emergence from the redd, fry of Atlantic salmon (Salmo salar L.) disperse in the nursery habitat. This dispersal, which may be extensive, lasts for a few weeks, but after early dispersion the salmon juveniles are supposed to be sedentary at least until October (SAUNDERS \& GEE, 1969 ; BEALL et al., 1994a). Changes in water conditions often occur during the summer months, usually with a period of low flows in mid to late summer. Reduced flows result in lower current velocity and depth, decreased availability of habitat and higher temperatures. According to BINNS \& EISERMAN (1979), if the average late summer stream flow falls below $10-15 \%$ of the yearly average, trout populations cannot be supported. Occasionnally in streams with dense populations of salmonids, there may be brief but drastic decreases of discharge which cause dewatering of riffles and reduce the stream to a succession of isolated pools.

Reactions of salmon parr to these changes are not well documented. LINDROTH (1955) noted that salmonid fry tended to move downstream after a decrease in water flow. SAUNDERS \& GEE (1969) observed the movement of parr into the nearest pool during a 
low flow period, and their return to the riffle after flow increase, but this concerned only three individuals. The objective of this study was to assess the movements of parr during or following a severe drop in discharge in semi-natural conditions.

\section{MATERIAL AND METHODS}

Three experiments were conducted in the controlled-flow stream channel of the INRA experimental station on Lapitxuri Brook in southwest France near St Pée sur Nivelle (see BEALL \& MARTY, 1983a for details). Each experiment was performed in a series of three 10-m long by 3-m wide sections of the channel. At the downstream end of each sequence, water was impounded so that depth increased from the upstream to the downstream section. The uppermost, shallowest section (1) corresponded to riffle habitat, the middle section (2) to flat, and the downstream section (3) to pool. Substrate in all sections comprised river gravel $1-8 \mathrm{~cm}$ in diameter. The channel bed was levelled with rakes to provide an homogenous habitat within each section, which were separated by two modified Wolfe traps (BEALL \& MARTY, 1983b). Depths could be manipulated and impoundments lowered by removing boards at the downstream end of the third section. Discharge was regulated by an intake valve, although precise control was not technically possible. Because of intake flow variations, only a general trend could be maintained. Water levels at a gauge placed at the upstream end of the channel and depths were recorded daily at 10:00 h. A series of 30 outflow measurements at different water levels recorded at the gauge generated two regression models between flow $\left(Q, I . s^{-1}\right)$ and water level $(\mathrm{H}, \mathrm{cm})$ :

$$
\begin{aligned}
& \mathrm{Q} 1=0.175 \mathrm{H}-6.48 \text { for } \mathrm{H}<56 \mathrm{~cm}\left(\mathrm{r}^{2}=0.27, \mathrm{p}=1.43, \mathrm{n}=21\right) \\
& \mathrm{Q} 2=10.463 \mathrm{H}-578.8 \text { for } \mathrm{H}>56 \mathrm{~cm}\left(\mathrm{r}^{2}=0.92, \mathrm{p}=0.0001, \mathrm{n}=9\right)
\end{aligned}
$$

Current velocities in the different sections at various water levels were calculated from these models. However, at very low water depths in the riffles, calculated water velocities increased very rapidly. This was found to be unrealistic because most of the water flowed through the gravel substrate, so these data were not included in the analyses. Minimum and maximum water temperatures were recorded continuously with a Jules Richard thermograph (Argenteuil, France), with the probe placed in the gravel of a section just below the experimental zone.

\subsection{Experiments $1 A$ and $1 B$}

These two experiments were conducted simultaneously between 13 and 27 August 1991 in two successive sequences of habitat, where each sequence was composed of three sections. The goal was to assess the migration of parr in response to drastically decreasing water levels. Two assumptions were made : (1) the number of fish remaining after 5 days corresponded to the capacity of the sections even when they could migrate only downstream and (2) migration during changes in water levels was the result of these changes only.

All sections for both experiments were stocked with 100 Atlantic salmon parr per section (3.5-3.6 ind. $\mathrm{m}^{-2}$, mean length $60.7 \mathrm{~mm}$, range $50-81 \mathrm{~mm}$ ). Those parr had emerged from other sections of the channel where they had reared on natural food until they were captured with electrofishing gear a few days prior to the experiment. The density was based on the number of parr found at capture. Initial densities of parr in the experiments were high when compared with data from natural environments (EGGLISHAW \& SHACKLEY, 1977 : up to 3.1 individuals. $\mathrm{m}^{-2}$; BEALL et al., 1994a: 0.4 ind. $\mathrm{m}^{-2}$ in the Lapitxuri brook in October). An experiment was run in the channel in a small enclosure, from emergence in April to the end of August 1991. Final density of $50-70 \mathrm{~mm}$ parr was 8 ind. $\mathrm{m}^{-2}$ (BEALL, unpublished results). This high carrying capacity of the channel was allowed by an abundant food supply and favorable environmental conditions (BEALL et al., 1994b).

During a 3-d acclimation period, parr moving downstream from any of the 10-m long sections were captured in traps and returned to their respective habitat. The experiment began on 16 August (day 1), when parr captured in traps were released in the adjacent downstream section, except those moving from the third section which were removed. Discharge was about $40 \mathrm{I.S}^{-1}$. Total bottom surface area, average depth (4 measurements 
Tableau I: Conditions initiales dans les biefs des expériences $1 \mathrm{~A}$ et 1B : surfaces (A), moyennes des profondeurs (D) et des vitesses du courant (V) ; valeurs extrêmes entre parenthèses.

Table I : Initial conditions in sections of Experiments 1A and 1B : areas (A), mean depth (D) and current velocity (V); ranges of values in parentheses.

\section{Experiment $1 \mathrm{~A}$}

\begin{tabular}{ccccccr} 
Section & $\mathrm{A}, \mathrm{m}^{2}$ & $\mathrm{D}, \mathrm{cm}$ & $\mathrm{V}, \mathrm{cm} \cdot \mathrm{s}^{-1}$ & $\mathrm{~A}, \mathrm{~m}^{2}$ & $\mathrm{D}, \mathrm{cm}$ & $\mathrm{V}, \mathrm{cm} \cdot \mathrm{s}^{-1}$ \\
1 & 27.8 & $12(8-16)$ & 9.5 & & & \\
2 & 28.0 & $33(29-46)$ & 3.2 & 28.2 & $9(4-11)$ & 12.6 \\
3 & 28.4 & $50(43-72)$ & 2.0 & 27.5 & $32(26-45)$ & 3.3 \\
\hline
\end{tabular}

Experiment 1B

A, $\mathrm{m}^{2} \quad \mathrm{D}, \mathrm{cm} \quad \mathrm{V}, \mathrm{cm} \cdot \mathrm{s}^{-1}$

28.2

$9(4-11)$

1

taken on 10 transects in each section) and average current velocity (discharge/crosssection) are shown in Table 1. Starting on day 6, water level decreased progressively over the subsequent 7 days until all sections were dewatered. Complete dewatering occurred during the last night of the experiment, due to the difficulty to control low flows at the intake valve and to decrease in the stream discharge. Traps were checked every morning, and all visible fish were recovered manually on the last day.

\subsection{Experiment 2}

The aim of this experiment was to monitor the movements of parr during decreasing and subsequent increasing water levels. It was conducted between 29 August and 24 September in the same sections as Experiment 1A, with the same initial conditions, except that discharge and water velocities were lower $\left(15 \mathrm{I} . \mathrm{s}^{-1}\right.$ and $1.1-5.1 \mathrm{~cm} . \mathrm{s}^{-1}$, respectively). Sections were stocked with salmon parr captured by electrofishing in the Lapitxuri brook (average length $=70.5 \mathrm{~mm}$, range 49-94). in the riffle, 84 (3.0 individuals. $\mathrm{m}^{-2}$ ), and in the flat and pool, 110 individuals per section $\left(4.0\right.$ ind $\left.\mathrm{m}^{2}\right)$ were released. During the first 3 days of acclimation, fish were trapped and returned to their respective sections as in experiments $1 \mathrm{~A}$ and $1 \mathrm{~B}$. The experiment started on first September (day 1), when trapped parr were released in the downstream section. Water levels were lowered for 4 days starting on day 8 . On day 11, the riffle, but not the flat and pool, was dewatered. Levels were increased again on day 13 for 3 days, and then remained constant until the end of the experiment. On day 13, traps at the end of the riffle and flat sections were removed to allow parr to migrate upstream. Traps in the pool were maintained and visited every morning. At the end of the experiment, all sections were closed off with screens and electrofished. The number of fish in each section was estimated from captures in 4 to 5 successive runs over a two day period, until no more fish were caught. Control of the traps in the subsequent days, and a last run of electrofishing indicated that fishing efficiency was close to $100 \%$.

\section{RESULTS}

\subsection{Experiments $1 A$ and $1 B$}

At the end of the experiments, numbers of parr recovered on the substrate were 18 , 106,94 , and $8,73,94$ in riffles, flats, and pools of exps. 1A \& 1B, respectively. Only 6 and 10 fish emigrated downstream from the pools. Thus, 74.7 and $61.7 \%$ of the parr were recovered in the two experiments. Other mortalities could not be collected because they were hidden in the substrate. 

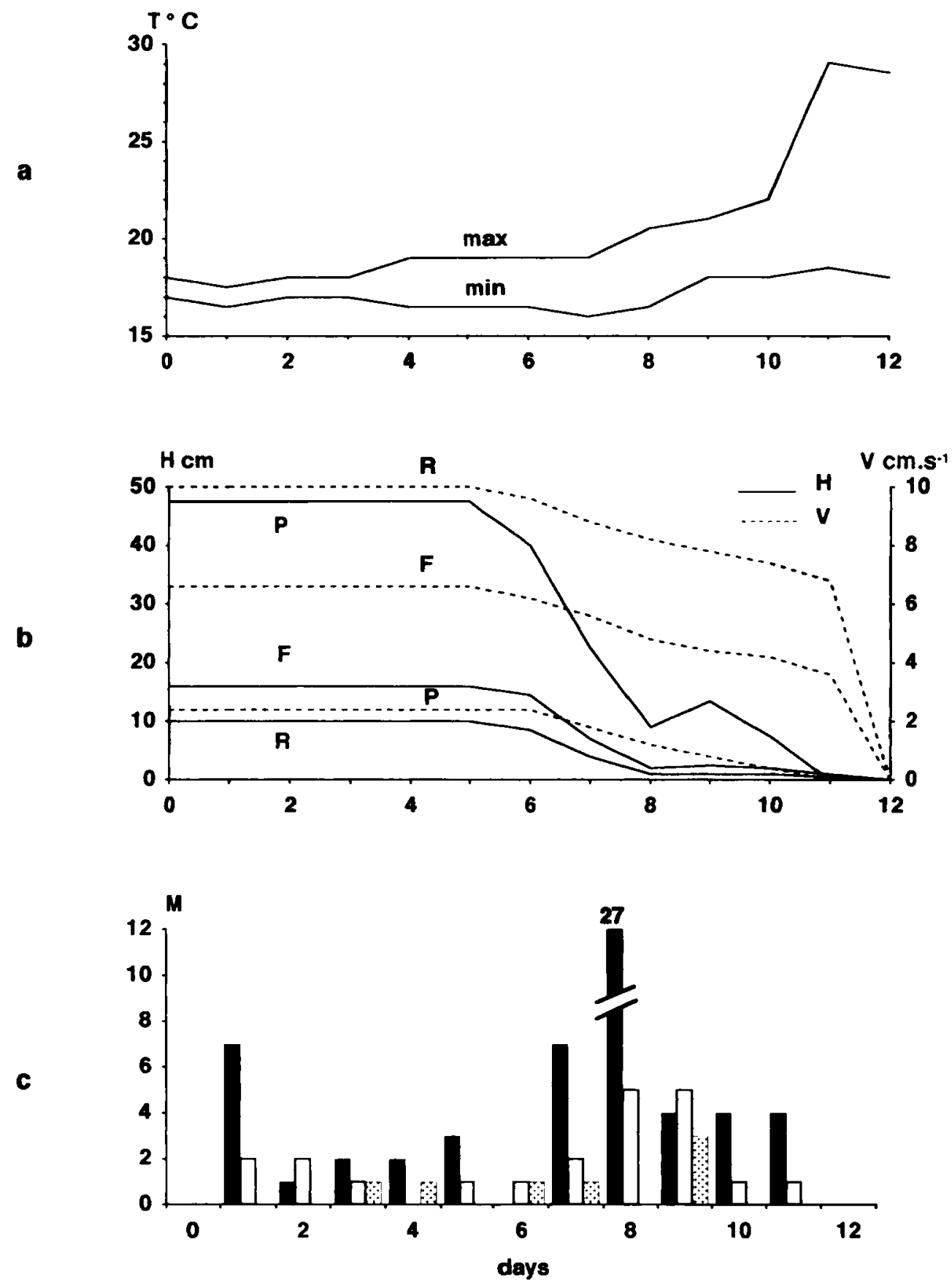

Figure 1 : Expérience $1 \mathrm{~A}$. a : températures de l'eau minima et maxima. $b$ : profondeur $H$ et vitesse du courant $V$ dans 3 biefs du chenal (radier: $R$; plat : $F$; profond : P). $c$ : nombre de migrants $M$ capturés dans les pièges aval (D radier ; $\square$ plat ; profond).

Figure 1 : Conditions in experiment 1A. a : minimum and maximum water temperatures. $b$ : water level $H$ and velocity $V$ in 3 sections of the channel (riffle : R ; flat : F ; pool : P). $c$ : number of migrants $M$ caught in traps (口 riffle ; $\rceil$ flat ; mool). 

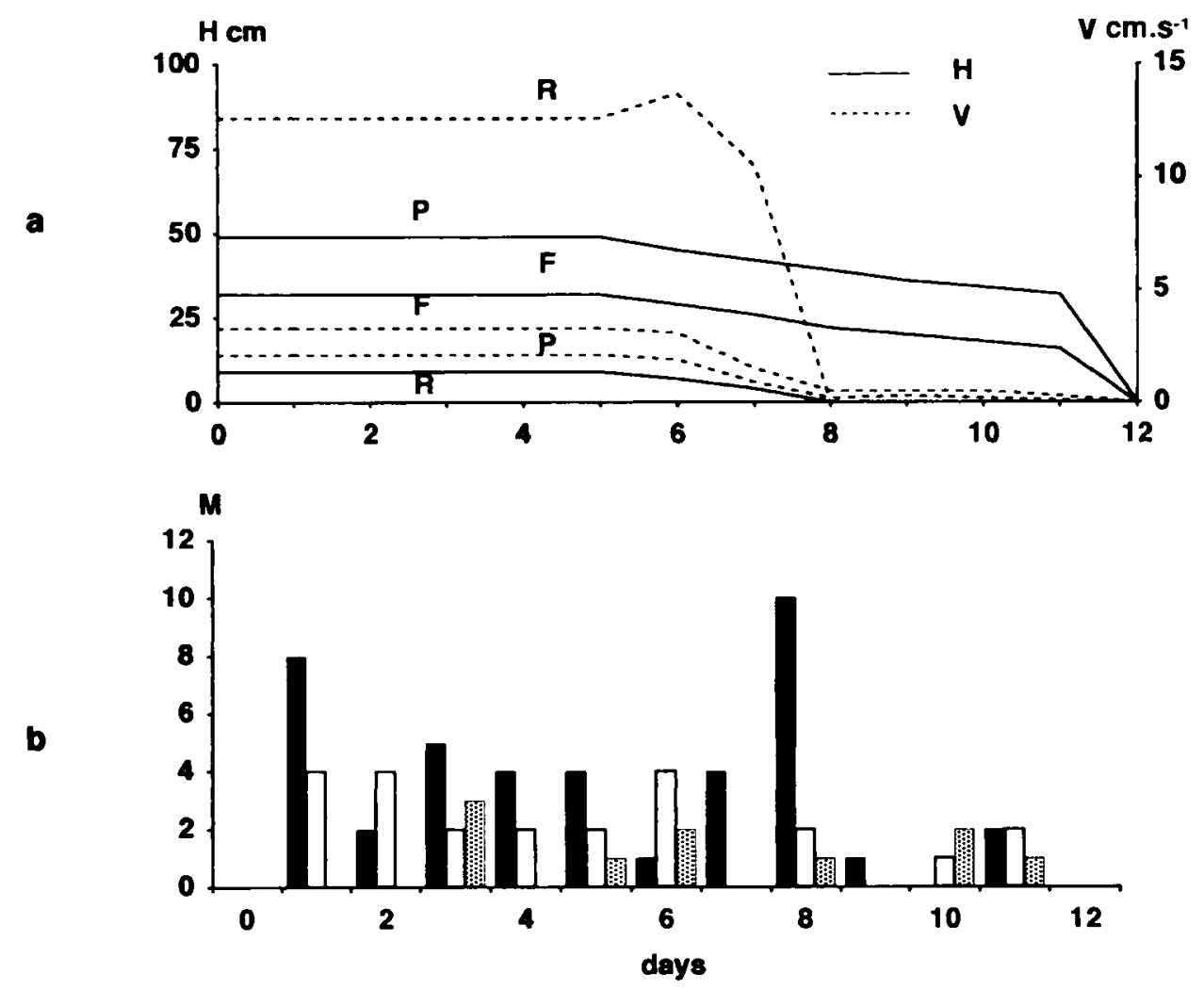

Figure 2 : Expérience 1B. a : profondeur $H$ et vitesse du courant $V$ dans 3 biefs du chenal. $b$ : nombre de migrants $M$ capturés dans les pièges aval ( 1 radier ; $\square$ plat ;

Figure 2 : Conditions in experiment 1B. a : water level $H$ and velocity $V$ in 3 sections of the channel. $b$ : number of migrants $M$ caught in traps (D riffle ; $\square$ flat ; pool).

During the first week of tests, minimum and maximum water temperatures remained relatively constant, between 16 and $19^{\circ} \mathrm{C}$, but started to increase as water levels decreased (Fig. 1a,b). A sharp rise in maximum temperature was recorded on the last day when dewatering occurred near the probe, and an air temperature of $29^{\circ} \mathrm{C}$ was noted. Patterns of movements were similar in the two experiments (Fig. 1c and 2b). During the first period, when water levels were constant (Fig. $1 \mathrm{~b}$ and $2 \mathrm{a}$ ), fish emigrated in rather small numbers and mainly from riffles. Movements increased rapidly, especially in exp. 1A, after a severe reduction in flow and depth, but nearly all migrants were from riffles. In exp. 1A, where the riffle was dewatered on the 11th day only, emigration decreased but still occurred. In exp. 1B, where average depth of the riffle was at 0 as early as day 8 , emigration stopped almost completely because of the lack of water.

\subsection{Experiment 2}

At the end of the experiment, numbers captured by electrofishing were 19, 116, and 108. Taking into account 27 fish which had emigrated downstream from the pool, mortality amounted to $11.2 \%$. 
a

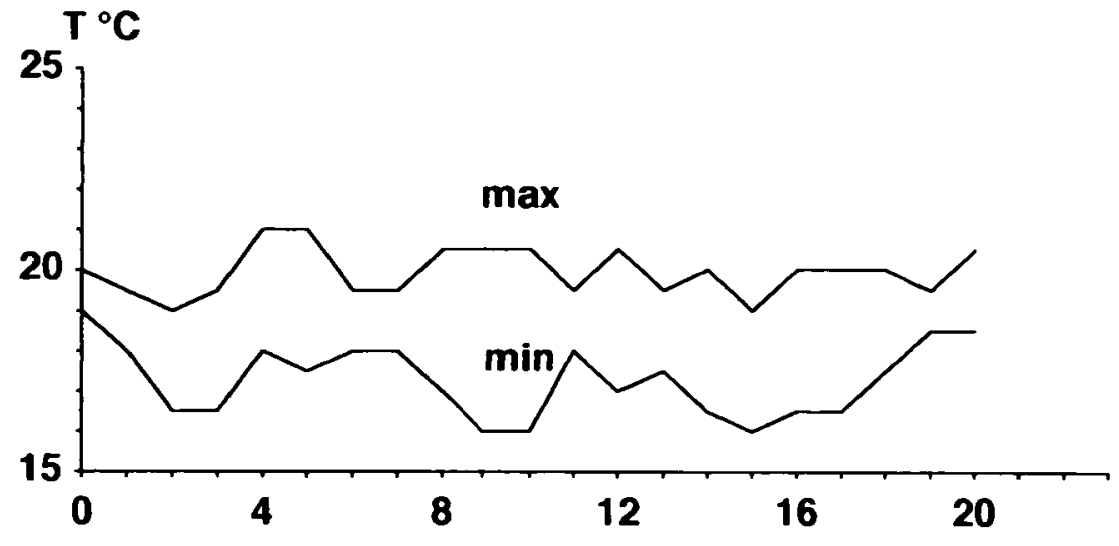

b
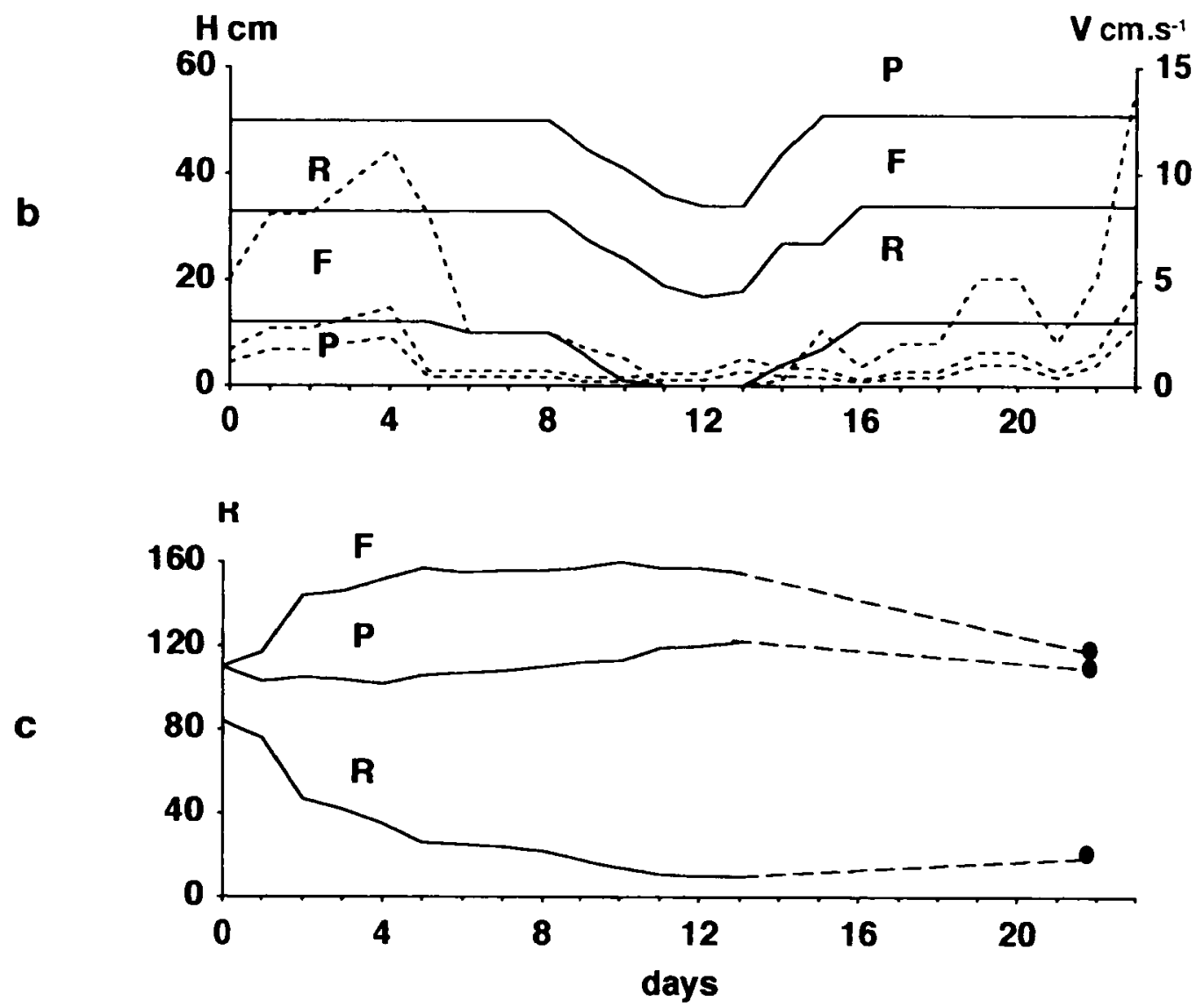

Figure 3 : Expérience 2. a : températures minima et maxima. $\mathrm{b}$ : profondeur $\mathrm{H}$ et vitesse $V$ dans 3 biefs du chenal. $c$ : nombre de poissons restant dans les biefs jusqu'au retrait des pièges le 13 ème jour $(R) ; \bullet$ : résidents capturés par pêche électrique en fin d'expérience.

Figure 3 : Conditions in experiment 2. a : minimum and maximum water temperatures. $b$ : water level $H$ and velocity $V$ in 3 sections of the channel. C : number of fish remaining in sections until removal of traps on day 13 (R) ; : residents captured by electrofishing at the end of the experiment. 
Water temperatures remained constant during the duration of the experiment (maximum temperature $=20 \pm 1{ }^{\circ} \mathrm{C}$, Fig. 3a). There was an increase in water velocity over 4 days and an intense migration, mainly from the riffle, during the first two days of the experiment (Fig. 3b,c). Estimated numbers of fish in sections changed significantly, 47, 144, and 105 parr in the riffle, flat, and pool, respectively. Then the rate of migration decreased gradually, increased slightly during lowering of the water level, and stopped almost completely in all sections after dewatering of the riffle. At the beginning of the second phase of the experiment (increase of the water level), the estimated numbers of fish in successive sections were 10,155 and 122. At the end, numbers of parr had decreased in the flat and pool sections, but slightly increased in the riffle (Fig. $3 \mathrm{c}$ ).

Mean lengths of fish at the beginning $(L=70.5 \mathrm{~mm}, \mathrm{n}=100)$ and end (riffle $: L 1=$ $68.1 \mathrm{~mm}, \mathrm{n}=19$; flat: $\mathrm{L} 2=68.7 \mathrm{~mm}, \mathrm{n}=50$; pool : $\mathrm{L} 3=74.2 \mathrm{~mm}, \mathrm{n}=50$ ) of the experiment were different at the $1 \%$ level (ANOVA, $F=4.03$ ). The Duncan multiple range test indicated that, at the end, parr from the pool were significantly larger than fish from the riffle and flat sections, but not from the average length of fish at the beginning of the experiment.

\section{DISCUSSION}

In all the experiments movements were mainly from riffles to flats, so that the numbers of salmon decreased in riffles and increased in flats. Small migrations from flats to pools were balanced by emigration out of the experimental reaches. The number of fish in pools varied little during the experiments. Decrease in density in the riffles during the first 5 days of experiments $1 A$ and $1 B$ in comparison with experiment 2 was small (15 and $23 \%$ vs. $69 \%$ ). Fish did not respond with increased movements to small changes in water levels in any experiment. A strong decrease caused large movements from riffles, but also from flats until dewatering of riffles.

In summer, salmon parr prefer shallow water habitat, with depths between 10 and 50 cm (KEENLEYSIDE, 1962 ; SYMONS \& HELAND, 1978 ; MORANTZ et al., 1987) and moderate current velocities of $5-15 \mathrm{~cm} . \mathrm{s}^{-1}$ (MORANTZ et al., 1987 ; HUNTINGFORD et al., 1988). Thus, initial conditions in all experiments were nearly optimal except water velocities in pools. In riffles, many species of juvenile salmonids are in contact with the substrate (MASON, 1969). In deeper places with slower flow they are often distributed throughout the water column (HARTMAN, 1963; MASON, 1969) and change their behaviour from territorial to schooling (KALLEBERG, 1958 ; CAMPBELL et al., 1984). Density of fish can thus be much higher (GRANT \& KRAMER, 1990). The present study supports this idea. Densities in riffles decreased, but increased in the nearest deeper sections, up to 5.64 individuals. $\mathrm{m}^{2}$. Parr in deep sections were observed swimming in small schools.

Brown trout (S. trutta) parr did not migrate in response to flow variations in HEGGENES (1988) experiments. The same was reported for rainbow trout (Oncorhynchus mykiss) by CAMPBELL et al (1984) and IRVINE (1987). In the present study emigration occurred only after drastic decreases in water levels and mainly from sections which were dewatered. But even then, high proportions of fish stayed and died (experiments $1 \mathrm{~A}$ and 1B). Observations made simultaneously in the enclosure during the decrease in water level indicated that parr reduced their activity, hid in the substrate and even buried themselves to a depth of several centimeters. They returned to the substrate surface as water flow came back to normal, but none was observed to migrate.

Analysis of growth in experiment 2 provided additional information. If we assume that growth rate of parr in the Lapitxuri brook is similar to that in the channel, then we can estimate, on the basis of data by BEALL et al. (1994b), the length which parr should have achieved at the end of the experiment $(76.5 \mathrm{~mm})$. The observed mean length of fish in the pool $(74.2 \mathrm{~mm}$ ) does not differ from the expected value, but both are larger than the observed lengths in the riffle and flat sections. Moreover, there was no significant growth in these two sections, in spite of the adequate food supply. One explanation would be that the larger fish from the riffle and flat sections moved into the deeper habitat of the pool, as a result of microhabitat preferences (SYMONS \& HELAND, 1978). However, because 
exchange of fish in the pool was small, and interchange between the riffle and the flat was high, another possible explanation is that fish in the deepest section fed normally, whereas they did not in the shallower zones. This is consistent with observations in the enclosure.

Our conclusion is that in deep water, salmon parr do not react to decreasing water levels and discharge. In shallower zones, however, they decrease their activity and feeding and in critical conditions, a proportion moves downstream to the nearest deep habitat. The others remain and burrow into the substrate. After return of higher flow conditions, a fraction of the migrants may move back to the riffle habitat.

\section{REFERENCES}

BEALL E., MARTY C., 1983a. Reproduction du saumon atlantique, Salmo salar L., en milieu semi-naturel contrôlé. Bull. Fr. Piscic., 289, 77-93.

BEALL E., MARTY C., 1983b. Dévalaison et survie d'alevins de saumon atlantique, Salmo salar L., en milieu semi-naturel contrôlé. Bull. Fr. Piscic., 290, 135-148.

BEALL E., DUMAS J., CLAIREAUX D., BARRIERE L., MARTY C., 1994a. Dispersal patterns and survival of Atlantic salmon (Salmo salar L.) juveniles in a nursery stream. ICES J. mar. Sci., 51, 1-9.

BEALL E., MARTY C., DUMAS J., HELAND M., 1994b. Etude des modalités de dispersion des juvéniles de saumon atlantique à partir de la frayère en ruisseau naturel ou expérimental. Final Report, Convention Etat-Région Aquitaine, 2691A, Station d'Hydrobiologie, INRA, Saint-Pée-sur-Nivelle, 61 p. + annexes.

BINNS N.A., EISERMAN F.M., 1979. Quantification of fluvial trout habitat in Wyoming. Trans. Am. Fish. Soc., 108, 215-228.

CAMPBELL R.N.B., RIMMER D.M., SCOTT D., 1984. The effect of reduced discharge on the distribution of trout. In LILLEHAMMER A. and SALTVEIT S.J. (Eds.), Regulated rivers, 407-416. Universitetsforlaget AS, Oslo, Norway.

EGGLISHAW H.J., SHACKLEY P.E., 1977. Growth, survival and production of juvenile salmon and trout in a Scottish stream, 1966-1975. J. Fish Biol., 11, 647-672.

GRANT J.W.A., KRAMER D.L., 1990. Territory size as a predictor of the upper limit to population density of juvenile salmonids in streams. Can. J. Fish. Aquat. Sci., 47, 1724-1737.

HARTMAN G.F., 1963. Observations on behaviour of juvenile brown trout in a stream aquarium during winter and spring. J. Fish. Res. Bd Can., 20, 769-787.

HEGGENES J., 1988. Effects of short-term flow fluctuations on displacement of, and habitat use by, brown trout in a small stream. Trans. Amer. Fish. Soc., 117, 336-344.

HUNTINGFORD F.A., METCALFE N.B., THORPE J.E., 1988. Choice of feeding station in Atlantic salmon, Salmo salar, parr : effects of predation risk, season and life history strategy. J. Fish Biol., 33, 917-924.

IRVINE J.R., 1987. Effects of varying flows in man-made streams on rainbow trout (Salmo gairdneri Richardson) fry. In CRAIG J.F. and KEMPER J.B. (Eds.), Regulated streams, 83-97, Plenum Publishing Corporation, 1987.

KALLEBERG H., 1958. Observations in a stream tank of territoriality and competition in juvenile salmon and trout (Salmo salar L. and S. trutta L.). Rep. Inst. Freshwat. Res. Drottningholm, 39, 55-98.

KEENLEYSIDE M.H.A., 1962. Skin diving observations of Atlantic salmon and brook trout in the Miramichi River, New Brunswick. J. Fish. Res. Bd Can., 19, 625-634.

LINDROTH A., 1955. Distribution, territorial behaviour and movements of sea trout fry in the river Indalsälven. Rep. Inst. Freshwat. Res. Drott., 36, 104-119. 
MASON J.C., 1969. Hypoxial stress prior to emergence and competition among coho salmon fry. J. Fish. Res. Bd Can., 26, 63-91.

MORANTZ D.L., SWEENEY R.K., SHIRVELL C.S., LONGARD D.A., 1987. Selection of microhabitat in summer by juvenile Atlantic salmon (Salmo salar). Can. J. Fish. Aquat. Sci., 44, 120-129.

SAUNDERS R.L., GEE J.H., 1969. Movements of young Atlantic salmon in a small stream. J. Fish. Res. Bd Can., 21, 27-36.

SYMONS P.E.K., HELAND M., 1978. Stream habitats and behavioral interactions of underyearling and yearling Atlantic salmon (Salmo salar). J. Fish. Res. Bd Can., 35, 175-183. 